\title{
Role of Thyroid Hormones in Apolipoprotein A-I Gene Expression in Rat Liver
}

Wolfgang Strobl, Nancy L. Gorder, Yen-Chiu Lin-Lee, Antonio M. Gotto, Jr., and Wolfgang Patsch
Department of Medicine, Baylor College of Medicine, and The Methodist Hospital, Houston, Texas 77030

\begin{abstract}
To study the regulation of hepatic apo A-I gene expression, we measured synthesis and abundance of cellular apo A-I mRNA and its nuclear precursors in livers of hypothyroid and hyperthyroid rats. In hypothyroid animals, both synthesis and abundance of apo A-I mRNA was reduced to half of control values. After injection of a receptor-saturating dose of triiodothyronine into euthyroid rats, apo A-I gene transcription increased at $20 \mathrm{~min}$, reached a maximum of $179 \%$ of control $(P<0.01)$ at $3.5 \mathrm{~h}$, and remained elevated for up to $48 \mathrm{~h}$. The abundance of nuclear and total cellular apo A-I mRNA increased at 1 and 2 $h$, respectively, and exceeded the levels expected from enhanced transcription more than twofold at $24 \mathrm{~h}$ after hormone injection. Upon chronic administration of thyroid hormones, levels of nuclear and cytoplasmic apo A-I mRNA remained elevated but transcription of the apo A-I gene fell to $42 \%$ of control $(P<0.01)$. Thus, thyroid hormones rapidly stimulate apo A-I gene transcription. Posttranscriptional events leading to increased stability of nuclear apo A-I RNA precursors become the principal mechanism for enhanced gene expression in chronic hyperthyroidism and may cause feedback inhibition of apo A-I gene transcription. Our results furthermore imply that the majority of hepatic nuclear apo A-I RNA precursors are degraded in euthyroid animals. (J. Clin. Invest. 1990. 85:659667.) apoproteins $\bullet$ liver $\bullet$ biosynthesis $\bullet$ hormones $\bullet$ gene expression $\bullet$ mRNA stabilization
\end{abstract}

\section{Introduction}

The liver produces the majority of plasma lipoproteins (1), and hepatic lipoprotein biosynthesis is a principal determinant of plasma lipoprotein levels. Various dietary and hormonal perturbations have been exploited to gain insight into the regulatory mechanisms of hepatic apolipoprotein synthesis, transport, lipid association, and secretion of lipoproteins. Hormonal stimuli affecting hepatic apolipoprotein production include insulin (2-4), corticosteroids (5), sex steroids (6-8), and thyroid hormones (9-11). Thyroid hormones increase fatty acid synthesis, but also fatty acid oxidation and ketogenesis in rat liver (12). Hepatic apolipoprotein production is altered as well by thyroid hormones. Apo E production is reduced without changes in apo E mRNA abundance (11). The synthesis of apo B-48 in rat liver increases at the expense of apo B-100 due to an enhanced posttranscriptional introduc-

Part of this research was published in abstract form (1989. Clin. Res. 37:300A. [Abstr.]).

Received for publication $10 \mathrm{July} 1989$ and in revised form 20 October 1989.

J. Clin. Invest.

(c) The American Society for Clinical Investigation, Inc.

0021-9738/90/03/0659/09 \$2.00

Volume 85, March 1990, 659-667 tion of a stop codon into apo B-100 mRNA (13). The net production of both apo A-I and apo A-IV in rat liver is increased (10) and can be accounted for by increases in apo A-I and apo A-IV mRNA abundance $(9,11)$. Thus, thyroid hormones affect the biosynthesis of individual apoproteins at distinct levels of gene expression. Studies in hyperthyroid rats further showed that apo A-I production was independent of VLDL production since the decreased output of VLDL in the hyperthyroid state was reversed by increasing the hepatic concentration of glycero-3-phosphate without altering the stimulated production of apo A-I (14).

The molecular events whereby thyroid hormones increase mRNA levels of hormone responsive genes are complex and may comprise a number of mechanisms. Increased transcription plays an important role in the induction of several genes by thyroid hormones, including those coding for growth hormone (reviewed in reference 15), $\alpha$-myosin heavy chain (16), and ornithine transcarbamylase (17). Stabilization of nuclear mRNA precursors is probably the predominant mechanism of the induction of S14 mRNA in rat liver by thyroid hormones (18). The $\mathrm{S} 14$ gene is expressed at high levels in brown adipose tissue and may code for a lipogenic enzyme (19). Decreased catabolism of the mature mRNA has been implicated in the rise of malic enzyme (20) and 3-hydroxy-3-methylglutarylcoenzyme A reductase (21) mRNA levels in response to thyroid hormones.

To understand the stimulatory effect of thyroid hormones on hepatic apo A-I biosynthesis, we studied the effect of these hormones on apo A-I gene transcription rates, and nuclear and total cellular apo A-I mRNA abundance in rat liver. We report that thyroid hormones rapidly increase apo A-I gene transcription. The major effect of thyroid hormones on apo A-I gene expression, however, is posttranscriptional, and can be explained by stabilization of nuclear apo A-I RNA. Prolonged thyroid hormone administration actually decreases apo A-I gene transcription, while nuclear apo A-I RNA and total cellular apo A-I mRNA remain elevated. These findings are consistent with a feedback inhibition of apo A-I gene transcription by the abundance of nuclear apo A-I RNA (22).

\section{Methods}

[ $\left.3^{\prime}, 5^{\prime}-{ }^{3} \mathrm{H}\right] \mathrm{UTP}(35 \mathrm{Ci} / \mathrm{mM})$ was purchased from ICN Radiochemicals (Irvine, CA), and [5'-32 P]UTP $(800$ or $3,000 \mathrm{Ci} / \mathrm{mM})$ and [5'-32 P]dCTP $(2,000 \mathrm{Ci} / \mathrm{mM})$ were from New England Nuclear (Boston, MA). Restriction enzymes were obtained from Boehringer Mannheim Biochemicals (Indianapolis, IN) or Bethesda Research Laboratories (Gaithersburg, MD). RNase-free DNase I, RNA-dependent RNA polymerase from Escherichia coli, $\alpha$-amanitin, and actinomycin D were from Boehringer Mannheim Biochemicals. Nitrocellulose (BA 85) was purchased from Schleicher \& Schuell, Inc. (Keene, NH), and Zeta Probe ${ }^{\otimes}$ nylon membranes were obtained from Bio-Rad Laboratories (Richmond, CA).

Adult male Sprague-Dawley rats (Texas Animal Specialties, Humble, TX) weighing $\sim 250 \mathrm{~g}$ were housed in a room with a 12-h light 
cycle (7-19 h). Animals were fed normal rat chow ad lib. Triiodothyronine $\left(T_{3}\right)^{1}$ and thyroxine $\left(T_{4}\right)$ were dissolved in $0.15 \mathrm{M} \mathrm{NaCl}, \mathrm{pH} 11$. Animals were injected subcutaneously or intraperitoneally as indicated under Results. Rats serving as injection controls received the alkaline saline only. Hypothyroidism was induced by feeding rat chow containing $0.1 \%$ propylthiouracil (ICN Nutritional Biochemicals, Cleveland, $\mathrm{OH}$ ). Food was removed at 9 a.m., and rats were anesthetized with diethylether 1-7 $\mathrm{h}$ later. Triglycerides and cholesterol were determined by enzymatic methods $(23,24)$. Plasma apo A-I $(25), T_{3}$, and $T_{4}$ (Quantimune ${ }^{\otimes} \mathrm{T}_{3}$ and $\mathrm{T}_{4}$ RIA; Bio-Rad Laboratories) were measured by RIA.

The recombinant plasmids used in this study included a recombinant plasmid pGEM-3 containing a full-length apo A-I cDNA insert, kindly provided by $\mathrm{L}$. Chan, a recombinant plasmid pBR 322 containing the entire coding sequence of rat apo $\mathrm{E}(26,27)$, and the plasmid clone pRSA57 containing 750 bp of the rat albumin gene (28) in a pBR322 vector. The probes were cut from the vectors with Pst I or Eco $\mathrm{RI}$, isolated by agarose gel electrophoresis, and labeled with $\left[{ }^{32} \mathrm{P}\right] \mathrm{dCTP}$ by nick translation (29).

Total RNA was extracted from $1 \mathrm{~g}$ of liver tissue by the guanidine hydrochloride method (30). The abundance of apo A-I, apo E, and albumin mRNA was determined by quantitative slot blotting (30). Increasing amounts $(0.5,1$, and $2 \mu \mathrm{g})$ of RNA were applied to nitrocellulose filters and hybridized to the ${ }^{32} \mathrm{P}$-labeled cDNA probes. Radioactivity was quantified by liquid scintillation counting. Relative abundance of apo A-I, apo E, and albumin mRNA was calculated from the slopes of the hybridization signals. Northern transfer of RNA was performed as outlined by Thomas (31). Total liver RNA was denatured with $1 \mathrm{M}$ glyoxal, 50\% DMSO and separated by electrophoresis in $1.2 \%$ agarose. The RNA was transferred to Zeta Probe ${ }^{\oplus}$ nylon membranes by diffusion blotting and hybridized to ${ }^{32} \mathrm{P}$-labeled $\mathrm{CDNA}$. The relative abundance of $\mathrm{mRNA}$ was determined from the intensities of the bands, which were quantified by soft laser densitometry. Probe stripping and rehybridization were carried out according to the manufacturer's recommendation.

Isolated liver cell nuclei were prepared by the method of Northemann et al. (32) as previously described (27). $6 \mathrm{~g}$ of liver were homogenized at $4^{\circ} \mathrm{C}$ in $10 \mathrm{mM}$ Tris $/ \mathrm{HCl}, 0.3 \mathrm{M}$ sucrose, $5 \mathrm{mM} \mathrm{MgCl}_{2}$, and $0.1 \%$ Triton X-405 with a Potter-Elvehjem tissue grinder. The homogenate was filtered through cheesecloth and adjusted to $1.6 \mathrm{M}$ sucrose with $10 \mathrm{mM}$ Tris/ $\mathrm{HCl}, \mathrm{pH} 7.5,2.3 \mathrm{M}$ sucrose, $5 \mathrm{mM}$ dithiothreitol, and $5 \mathrm{mM} \mathrm{MgCl}$. The nuclei were sedimented through $2.3 \mathrm{M}$ sucrose, $10 \mathrm{mM} \mathrm{Tris} / \mathrm{HCl}, \mathrm{pH} 7.5$, and $2 \mathrm{mM} \mathrm{MgCl}{ }_{2}$ in a rotor (SW-27; Beckman Instruments, Inc., Palo Alto, CA) at $20,000 \mathrm{rpm}$ for $60 \mathrm{~min}$. The nuclear pellet was resuspended in $800 \mu 1$ of $50 \mathrm{mM}$ Hepes buffer, pH 7.5 , containing $50 \%$ glycerol, $5 \mathrm{mM} \mathrm{MgCl}$, and $0.1 \mathrm{mM}$ EDTA, and frozen in aliquots at $-70^{\circ} \mathrm{C}$. The DNA content in the nuclei was determined by a fluorimetric assay according to the method of Kapuscinski and Skoczylas (33) using salmon sperm DNA as a standard.

Cell-free transcription was performed by the method of Birch and Schreiber (34) as previously described (27). Briefly, isolated nuclei were allowed to continue RNA synthesis initiated in vivo in a reaction mix containing $50 \mathrm{mM}$ Hepes, pH 7.5, $50 \mathrm{mM} \mathrm{NaCl}, 2.5 \mathrm{mM} \mathrm{MgCl}_{2}, 0.05$ mM EDTA, $5 \mathrm{mM}$ dithiothreitol, $1 \mathrm{mM}$ ATP, $1 \mathrm{mM} \mathrm{CTP,} 1 \mathrm{mM}$ GTP, $2 \mathrm{mM}$ creatine phosphate, $2 \mu \mathrm{g}$ creatine phosphokinase, $25 \%$ glycerol, $20 \mu \mathrm{g}$ heparin, $1 \mathrm{mM}$ spermin, $1 \mathrm{mM}$ EGTA, $0.1 \mathrm{mM}$ PMSF, $50 \mathrm{U}$ of human placental ribonuclease inhibitor, and $100 \mu \mathrm{Ci}$ of $\left[{ }^{32} \mathrm{P}\right]-$ UTP in a final volume of $200 \mu \mathrm{l}$ at $25^{\circ} \mathrm{C}$ for $30 \mathrm{~min}$. After incubation, nuclei were digested with $150 \mu \mathrm{g} / \mathrm{ml}$ proteinase $\mathrm{K}$ and $0.5 \%$ SDS for 30 min at $37^{\circ} \mathrm{C}$. Nucleic acids were extracted twice with phenol/chloroform/isoamylalcohol (25:24:1, vol/vol/vol) and precipitated from the aqueous phase with ethanol. DNA was digested with DNase I, and RNA was extracted with phenol/chloroform/isoamylalcohol. Unin-

1. Abbreviations used in this paper: $\mathrm{T}_{3}$, triiodothyronine; $\mathrm{T}_{4}$, thyroxine. corporated [ $\left.{ }^{32} \mathrm{P}\right]$ UTP was removed by precipitation of the RNA with TCA (35). After a final ethanol precipitation, RNA was dissolved in 10 $\mathrm{mM}$ Tris/HCl, $\mathrm{pH}$ 8.0, and $1 \mathrm{mM}$ EDTA. Total $\left[{ }^{32} \mathrm{P}\right] \mathrm{UTP}$ incorporation ranged from 0.15 to $0.40 \mathrm{pM} / \mu \mathrm{g}$ DNA per min. Under our experimental conditions transcription was DNA dependent, and RNA polymerase II activity amounted to $55 \%$ of total transcription as previously reported (27). Transcription from the albumin and apolipoprotein genes was completely abolished by $2.5 \mu \mathrm{g} / \mathrm{ml}$ amanitin (27). The newly synthesized ${ }^{32} \mathrm{P}$-labeled transcripts of the apo $\mathrm{E}$ and albumin genes were quantitated by dot blot hybridization to an excess (6-8 $\mu \mathrm{g})$ of plasmid containing the apo $\mathrm{E}$ or albumin cDNA inserts as previously described (27). To measure the transcriptional activity of the apo A-I gene, 6-8 $\mu \mathrm{g}$ of plasmid containing a full-length apo A-I cDNA insert were immobilized on nitrocellulose membranes by dot blotting (36). Nonrecombinant plasmid pGEM-3 was used to determine nonspecific hybridization. Alternatively, the apo A-I cDNA insert was cut from the pGEM-3 vector with Pst I and purified by agarose gel electrophoresis, and $3 \mu \mathrm{g}$ of the cDNA was used for dot blotting. Hybridization was carried out using 3-8 $\times 10^{6} \mathrm{cpm}$ of extracted nuclear [ $\left.{ }^{32} \mathrm{P}\right] \mathrm{RNA}$ under conditions identical to those described for apo $E$ and albumin. To monitor hybridization efficiency, ${ }^{3} \mathrm{H}$-labeled cRNAs of apo A-I, apo E, and albumin $(500-1,000 \mathrm{cpm})$ were included in the hybridization reactions. The $\left[{ }^{3} \mathrm{H}\right] \mathrm{cRNAs}$ were synthesized from the cDNA templates using DNA-dependent RNA polymerase as described by Roop et al. (37) and purified by hybridization to the respective recombinant plasmids immobilized on nitrocellulose (38). After hybridization, filters were washed twice with $2 \times$ standard saline citrate, $0.1 \%$ SDS for 30 min at room temperature, then once at $50^{\circ} \mathrm{C}$ and once at $55^{\circ} \mathrm{C}$ with $0.1 \times$ standard saline citrate, $0.1 \%$ SDS for $30 \mathrm{~min}$. Radioactivity was eluted from the filters with $0.3 \mathrm{M} \mathrm{NaOH}$ and the samples were counted for $20 \mathrm{~min}$ in a liquid scintillation counter. Under the conditions used the amount of $\left[{ }^{32} \mathrm{P}\right] \mathrm{RNA}$ hybridized to the filters was proportional to the $\left[{ }^{32} \mathrm{P}\right] \mathrm{RNA}$ input over a range of 4-14 $\times 10^{6} \mathrm{cpm}$, independent of the thyroid status of the animals. The relative rates of apo A-I, apo E, and albumin mRNA synthesis were calculated by subtracting the counts per minute of ${ }^{32} \mathrm{P}$ bound to the filters containing nonrecombinant plasmids (1-2 parts per million [ppm]) from the counts per minute of ${ }^{32} \mathrm{P}$ bound to the filters with plasmids containing the apo A-I, apo $\mathrm{E}$, or albumin cDNA inserts, and by dividing the counts per minute of ${ }^{32} \mathrm{P}$ bound by the [ $\left.{ }^{32} \mathrm{P}\right] \mathrm{RNA}$ input. Values were corrected for efficiency of hybridization and are given as parts per million of $\left[{ }^{32} \mathrm{P}\right]$ RNA input. As an additional evaluation of the assay, relative mRNA synthesis rates were corrected for probe length and the distribution of exons and introns within the part of the gene covered by the probe as described (36). Mean corrected mRNA synthesis rates for control animals were $3,800 \mathrm{ppm}$ for albumin, $250 \mathrm{ppm}$ for apo $\mathrm{E}$, and $181 \mathrm{ppm}$ for apo A-I. These results are consistent with earlier measurements on albumin and apo E gene transcription $(27,36)$.

Nuclear RNA was extracted by the method of Lamers et al. (39). Rat liver cell nuclei were isolated as described above. To inhibit ribonuclease and proteinase activity, $0.1 \mathrm{mM}$ EGTA, $0.1 \mathrm{mM}$ spermidine, $5 \mathrm{mM}$ dithiothreitol, and $0.1 \mathrm{mM}$ PMSF were included in all solutions used for homogenization and ultracentrifugation. $5 \mathrm{mM}$ dithiothreitol and $0.1 \mathrm{mM}$ PMSF were added to the storage buffer. Nuclei $\left(10^{8}\right.$ nuclei in $0.5 \mathrm{ml}$ of storage buffer) were disrupted by adding $6.4 \mathrm{ml}$ of $5 \mathrm{M}$ guanidine isothiocyanate, $25 \mathrm{mM}$ EDTA, $0.25 \mathrm{M}$ 2-mercaptoethanol, $0.63 \%$ sodium lauryl sulfate, and $62.5 \mathrm{mM}$ Pipes, $\mathrm{pH} 7.0$, at room temperature. DNA was sheared by passing it through an 18-gauge needle. Solid $\mathrm{CsCl}$ was added to a concentration of $1.4 \mathrm{M}$ and the volume was adjusted to $8 \mathrm{ml}$. RNA was isolated by centrifugation through a 4-ml cushion of $5.7 \mathrm{M} \mathrm{CsCl}, 0.1 \mathrm{mM}$ EDTA, pH 7.0, in a rotor (SW-41; Beckman Instruments, Inc.) at $30,000 \mathrm{rpm}$ for $18 \mathrm{~h}$ at $18^{\circ} \mathrm{C}$. The pellet was resuspended in $100 \mu \mathrm{l}$ of $10 \mathrm{mM}$ Hepes, $1 \mathrm{mM}$ EDTA, and $0.1 \%$ SDS, pH 7.5, and extracted once with phenol/chloroform/isoamylalcohol. RNA was precipitated from the aqueous phase with ethanol, redissolved in $50 \mu \mathrm{l}$ of RNase-free water, and stored at $-70^{\circ} \mathrm{C}$. Nuclear RNA was analyzed by Northern blotting and soft laser densitometry of autoradiograms. 
Table I. Effect of Chronic Hypo- and Hyperthyroidism on Apo A-I, Apo E, and Albumin mRNA Abundance and Apo A-I Gene Transcription in Rat Liver

\begin{tabular}{|c|c|c|c|c|c|c|}
\hline \multicolumn{2}{|r|}{ Group } & \multicolumn{3}{|c|}{ mRNA abundance } & \multirow{2}{*}{$\begin{array}{c}\text { Total } \\
\text { transcription }\end{array}$} & \multirow{2}{*}{$\begin{array}{c}\text { Apo A-I } \\
\text { mRNA } \\
\text { synthesis }\end{array}$} \\
\hline$T_{4}^{*}$ & Diet & Apo A-I & Apo E & Albumin & & \\
\hline & & & ppm & & $\mathrm{cpm} \times 10^{6}$ & \\
\hline - & Chow & $100 \pm 15$ & $100 \pm 14$ & $100 \pm 16$ & 12.84 & $79(77,81)$ \\
\hline 40 & Chow & $256 \pm 33^{\ddagger}$ & $113 \pm 18$ & $91 \pm 11$ & 14.45 & $66^{\ddagger}(64,68)$ \\
\hline - & $0.1 \%$ Propylthiouracil + chow & $56 \pm 2^{\ddagger}$ & $95 \pm 12$ & $98 \pm 3$ & 14.77 & $47^{\ddagger}(50,44)$ \\
\hline
\end{tabular}

Total cellular RNA was extracted from livers of individual animals ( $n=3$ pools/group, 2 rats/pool). The abundance of apo A-I, apo E, and albumin mRNA was determined by quantitative slot blotting and is expressed as percent of control. Values represent means \pm SEM. Apo A-I mRNA synthesis rates were measured by nuclear run-on assays using pooled liver cell nuclei from six rats/group. Hybridization was performed in duplicate. Results are corrected for hybridization efficiency $(21 \pm 5 \%)$. ${ }^{*}$ The dose of $\mathrm{T}_{4}$ is in $\mu \mathrm{g} / 100 \mathrm{~g}$ body weight and was administered subcutaneously daily for $21 \mathrm{~d} .{ }^{\ddagger} P<0.05$, one-way analysis of variance, Scheffe test.

\section{Results}

In an initial experiment, we followed a protocol similar to that of Apostolopoulos et al. (9), which was shown to raise hepatic apo A-I mRNA levels. Rats were injected daily subcutaneously with $40 \mu \mathrm{g} \mathrm{T} / 100 \mathrm{~g}$ body weight for $3 \mathrm{wk}$. Another group of animals was made hypothyroid with propylthiouracil. The groups fed the propylthiouracil diet gained less weight $(1.2 \pm 0.2 \mathrm{~g} / \mathrm{d}$, mean \pm SEM) than control $(5.4 \pm 0.8 \mathrm{~g} / \mathrm{d})$ or hyperthyroid rats $(3 \pm 0.4 \mathrm{~g} / \mathrm{d})$. Plasma $\mathrm{T}_{3}$ in control, $\mathrm{T}_{4}$-injected, and hypothyroid rats was $73 \pm 4,97 \pm 19$, and $61 \pm 1 \mathrm{ng} / \mathrm{dl}$, respectively (mean \pm SEM, $n=5-6 /$ group). Plasma $T_{4}$ levels in the same groups were $4.2 \pm 0.6,8.6 \pm 0.8$, and $0.5 \pm 0.1 \mu \mathrm{g} / \mathrm{dl}$ (mean \pm SEM) and differed from each other $(P<0.05$, analysis of variance, Scheffe test). No significant differences in plasma cholesterol and triglycerides were found between the groups.

The relative abundance of apo A-I mRNA in the livers of rats injected with $\mathrm{T}_{4}$ was increased to $256 \pm 33 \%$ of controls (mean \pm SEM, $P<0.05$ ) without changes in apo E or albumin mRNA levels (Table I). In hypothyroid rats, hepatic apo A-I mRNA levels fell and apo A-I mRNA synthesis was proportionally decreased. In contrast, the expected increase of hepatic apo A-I mRNA synthesis was not observed in rats made hyperthyroid; rather, apo A-I gene transcription amounted to only $83 \%$ of control values. In a second transcription assay using other aliquots of isolated nuclei from the same set of animals, the decrease of apo A-I gene transcription in hyperthyroid and hypothyroid rats was confirmed (data not shown). A similar pattern of transcription rates was observed in a third transcription assay performed with nuclei from these animals using the apo A-I cDNA insert only for hybridization. Thus, these initial experiments indicated a posttranscriptional stimulation of apo A-I gene expression as a result of prolonged thyroid hormone administration.

To study the time course and the relationship of apo A-I gene expression with the hormone dose administered, a second group of rats was injected daily with a nonreceptor saturating dose ( $7 \mu \mathrm{g} / 100 \mathrm{~g}$ body weight s.c.) or a nearly receptor-saturating dose $\left(35 \mu \mathrm{g} / 100 \mathrm{~g}\right.$ body weight s.c.) of $T_{3}$ for 3 or $7 \mathrm{~d}$. The low dose regimen had only minor effects on plasma $T_{3}$, while the high dose regimen resulted in $T_{3}$ levels above the concentration required to saturate $\sim 80 \%$ of hepatic $T_{3}$ receptors $(40)$ (Table II). A dose-related increase of plasma apo A-I was present at days 3 and 7 . The effect of $T_{3}$ on apo A-I mRNA levels was also fully established after $3 \mathrm{~d}$ of hormone injection. At both 3 and $7 \mathrm{~d}$ of treatment, the magnitude of the increase in apo A-I mRNA was correlated with the daily dose administered and the plasma levels of $T_{3}$ attained (Tables II and III, and Fig. 1). Hepatic apo E and albumin mRNA abundance was not altered by $T_{3}$ administration. Northern blots of total liver RNA confirmed the data from slot blots, in that only apo A-I mRNA abundance increased as a result of $T_{3}$ injections. No changes were noted in control injected animals, and none of the regimens altered the size of the mRNAs studied. As in the first set of animals, apo A-I gene transcription rates were decreased in livers from rats injected with $\mathrm{T}_{3}$ (Table III, Fig. 1). The decrease in apo A-I transcription was inversely correlated with the increase of plasma $T_{3}$ levels and total apo A-I mRNA abundance. No consistent effects of thyroid hormone on apo $E$ and albumin gene transcription were noted. Thus, these data showed a specific induction of apo A-I gene expression by $\mathrm{T}_{3}$, which was dose dependent and appeared to be governed by posttranscriptional events. To study the site of posttranscriptional upregulation, we measured the abundance of nuclear apo A-I, apo E, and albumin RNA in controls and animals receiving $35 \mu \mathrm{g} \mathrm{T} / 100 \mathrm{~g}$ body weight for $7 \mathrm{~d}$. In hyperthyroid animals, the abundance of nuclear apo A-I RNA was increased to $274 \%$ of control values without changes in nuclear apo $\mathrm{E}$ or albumin RNA levels. These preliminary data suggested that the enhanced apo A-I gene expression resulted from stabiliza-

Table II. Effect of Two Different Doses of $T_{3}$ on Plasma $T_{3}$ and Apo A-I Levels

\begin{tabular}{rccc}
\hline Treatment & Time & $\mathrm{T}_{3}$ & Apo A-I \\
\hline & $d$ & $n g / d l$ & $m g / d l$ \\
Control & - & $86 \pm 6$ & $60 \pm 3$ \\
$7 \mu \mathrm{g} \mathrm{T}_{3}$ & 3 & $103 \pm 7$ & $81 \pm 6$ \\
$35 \mu \mathrm{g} \mathrm{T}_{3}$ & 3 & $392 \pm 46^{*}$ & $110 \pm 4^{*}$ \\
$7 \mu \mathrm{g} \mathrm{T}_{3}$ & 7 & $134 \pm 16$ & $84 \pm 7$ \\
$35 \mu \mathrm{g} \mathrm{T}_{3}$ & 7 & $370 \pm 12^{*}$ & $122 \pm 12^{*}$
\end{tabular}

Rats (four to six/group) were injected daily with 7 or $35 \mu \mathrm{g} / 100 \mathrm{~g}$ body weight for 3 or 7 d. Plasma $T_{3}$ and apo A-I were determined by RIA. Data are means \pm SEM.

* $P<0.05$ vs. control, analysis of variance. 
Table III. Effect of Two Different Doses of $T_{3}$ on Hepatic Apo A-I, Apo E, and Albumin Abundance and Gene Transcription

\begin{tabular}{|c|c|c|c|c|c|c|c|}
\hline \multirow[b]{2}{*}{ Treatment } & \multirow[b]{2}{*}{ Time } & \multicolumn{2}{|c|}{ Apo A-I } & \multicolumn{2}{|c|}{ Apo E } & \multicolumn{2}{|c|}{ Albumin } \\
\hline & & $\begin{array}{c}\text { mRNA } \\
\text { abundance }\end{array}$ & $\begin{array}{c}\text { mRNA } \\
\text { synthesis }\end{array}$ & $\begin{array}{c}\text { mRNA } \\
\text { abundance }\end{array}$ & $\begin{array}{c}\text { mRNA } \\
\text { synthesis }\end{array}$ & $\begin{array}{c}\text { mRNA } \\
\text { abundance }\end{array}$ & $\begin{array}{l}\text { mRNA } \\
\text { synthesis }\end{array}$ \\
\hline & & $\%$ control & $p p m$ & \% control & $p p m$ & $\%$ control & $p p m$ \\
\hline Control & - & $100 \pm 9$ & $\begin{array}{c}77 \\
(85,68)\end{array}$ & $100 \pm 5$ & $\begin{array}{c}51 \\
(48,54)\end{array}$ & $100 \pm 4$ & $\begin{array}{c}293 \\
(303,282)\end{array}$ \\
\hline $7 \mu \mathrm{g} \mathrm{T}_{3}$ & 3 & $168 \pm 5^{*}$ & $\begin{array}{c}42^{*} \\
(41,43)\end{array}$ & $110 \pm 13$ & ND & $95 \pm 2$ & $\begin{array}{c}246 \\
(231,282)\end{array}$ \\
\hline $35 \mu \mathrm{g} \mathrm{T}_{3}$ & 3 & $334 \pm 5^{*}$ & $\begin{array}{c}32^{*} \\
(30,34)\end{array}$ & $85 \pm 7$ & $60 \pm 5$ & $127 \pm 6$ & $\begin{array}{c}303 \\
(261,344)\end{array}$ \\
\hline $7 \mu \mathrm{g} \mathrm{T}_{3}$ & 7 & $183 \pm 9^{*}$ & $\begin{array}{c}38^{*} \\
(39,36)\end{array}$ & $94 \pm 1$ & ND & $115 \pm 9$ & $\begin{array}{c}371 \\
(356,386)\end{array}$ \\
\hline $35 \mu \mathrm{g} \mathrm{T}_{3}$ & 7 & $286 \pm 3^{*}$ & $\begin{array}{c}21^{*} \\
(22,21)\end{array}$ & $92 \pm 13$ & $52 \pm 7$ & $96 \pm 3$ & $\begin{array}{c}362 \\
(329,395)\end{array}$ \\
\hline
\end{tabular}

Rats (four to six/group) were injected daily with $T_{3}(7$ or $35 \mu \mathrm{g} / 100 \mathrm{~g}$ body weight) for 3 or $7 \mathrm{~d}$. Total cellular RNA was extracted from livers and the abundance of apo A-I, apo E, and albumin mRNA was determined by quantitative slot blotting. Results are means \pm SEM. mRNA synthesis rates were determined by transcription assays using nuclei pooled from four to six animals/group. Hybridization was performed in duplicate or triplicate. Results are expressed in parts per million (ppm) of [ $\left.{ }^{32} \mathrm{P}\right] \mathrm{RNA}$ input $\left(8 \times 10^{6} \mathrm{cpm}\right.$ for apo A-I, $5.5 \times 10^{6} \mathrm{cpm}$ for apo E, and 4 $\times 10^{6} \mathrm{cpm}$ for albumin) and are corrected for hybridization efficiency ( $35 \pm 4 \%$ for apo A-I, $20 \pm 2 \%$ for apo $\mathrm{E}$, and $15 \pm 3 \%$ for albumin) as determined with ${ }^{3} \mathrm{H}$-labeled cRNA standards. ${ }^{*}$ Significantly different from control, $P<0.05$, two-way analysis of variance.
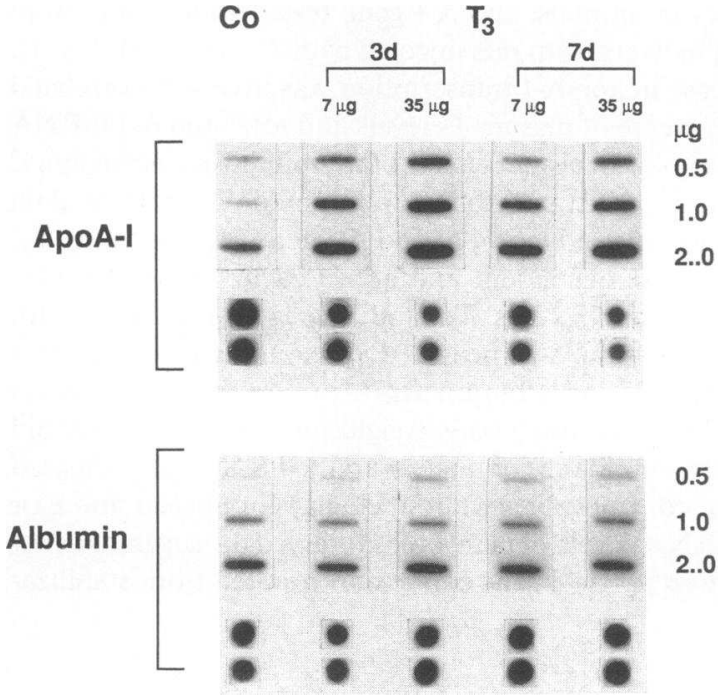

Figure 1. Slot blots of total liver RNA hybridized to ${ }^{32} \mathrm{P}$-labeled apo A-I and albumin cDNA inserts (rows 1 and 3 ) and dot blots of ${ }^{32} \mathrm{P}$ labeled nuclear RNA hybridized to excess apo A-I and albumin cDNA (rows 2 and 4). Rats (4-6/group) were injected with 7 or 35 $\mu \mathrm{g} / 100 \mathrm{~g}$ of $\mathrm{T}_{3}$ for 3 or $7 \mathrm{~d}$. Total liver RNA was extracted by the guanidine- $\mathrm{HCl}$ method, and increasing doses of RNA $(0.5,1$, and 2 $\mu \mathrm{g})$ were applied to nitrocellulose. After hybridization to ${ }^{32} \mathrm{P}$-labeled apo A-I or albumin cDNA, filters were exposed to x-ray film for 24 and $6 \mathrm{~h}$, respectively. Run-on transcription assays (rows 2 and 4 ) were performed using pooled liver cell nuclei from four to six animals per group. The newly synthetized [ $\left.{ }^{32} \mathrm{P}\right] \mathrm{RNA}$ was extracted and hybridized in duplicate to plasmids containing apo A-I or albumin cDNA inserts immobilized to nitrocellulose filters. Filters were exposed to $\mathrm{x}$-ray film for 24 or $12 \mathrm{~h}$, respectively. Under the conditions used, nonspecific hybridization to nonrecombinant plasmids was not detectable on the films. tion of nuclear apo A-I RNA rather than alterations in the metabolism of cytoplasmic apo A-I mRNA (see also below).

To examine the short-term effect of thyroid hormone on hepatic apolipoprotein gene expression, we followed the time course of gene transcription rates and nuclear and cellular mRNA abundance after a single intraperitoneal injection of $T_{3}$. The $T_{3}$ dose of $3 \mathrm{mg} / 100 \mathrm{~g}$ body weight was chosen to saturate the nuclear $T_{3}$ receptor throughout the course of the study (40). Apo A-I mRNA synthesis increased to $139 \pm 5 \%$ (mean \pm SEM) of controls at $20 \mathrm{~min}$ after $\mathrm{T}_{3}$ injection, the earliest timepoint studied, rose to $179 \pm 4 \%$ of controls at $3.5 \mathrm{~h}$, and remained significantly elevated for $48 \mathrm{~h}$ (Fig. 2). Transcription of the apo $\mathrm{E}$ gene was transiently increased to $153 \pm 73 \%$ (mean \pm SEM) of control $(P<0.05)$ at 20 min only, but then returned to baseline levels. Albumin gene transcription declined sharply after $1 \mathrm{~h}$, remained significantly reduced up to $6 \mathrm{~h}(P<0.05)$, but returned to baseline levels by $24 \mathrm{~h}$ after the injection. Mean (SEM) values of total transcription were 84 (14), 77 (14), 74 (17), 95 (6), 71 (7), 96 (20), and 81 (12)\% of control at $20 \mathrm{~min}, 1,2,3.5,6,24$, and $48 \mathrm{~h}$, respectively, and did not differ significantly from control (analysis of variance, Kruskall-Wallis test). On Northern blots of nuclear RNA (Fig. 3), at least three RNA species hybridized with the apo A-I cDNA probe. The rapid stimulation of apo A-I gene transcription was followed by an accumulation of the putative nuclear apo A-I mRNA precursors beginning $1 \mathrm{~h}$ after injection. However, the levels of nuclear apo A-I mRNA precursors continued to increase to $292 \%$ of control values at $24 \mathrm{~h}$, even after apo A-I gene transcription had reached a plateau. No changes in the proportions of nuclear apo A-I RNA species were noted. Several putative nuclear apo E mRNA precursor bands were visualized on Northern blots. The levels of these nuclear apo E RNA increased twofold by $2 \mathrm{~h}$ after $\mathrm{T}_{3}$ administration, but decreased thereafter to baseline values. The de- 


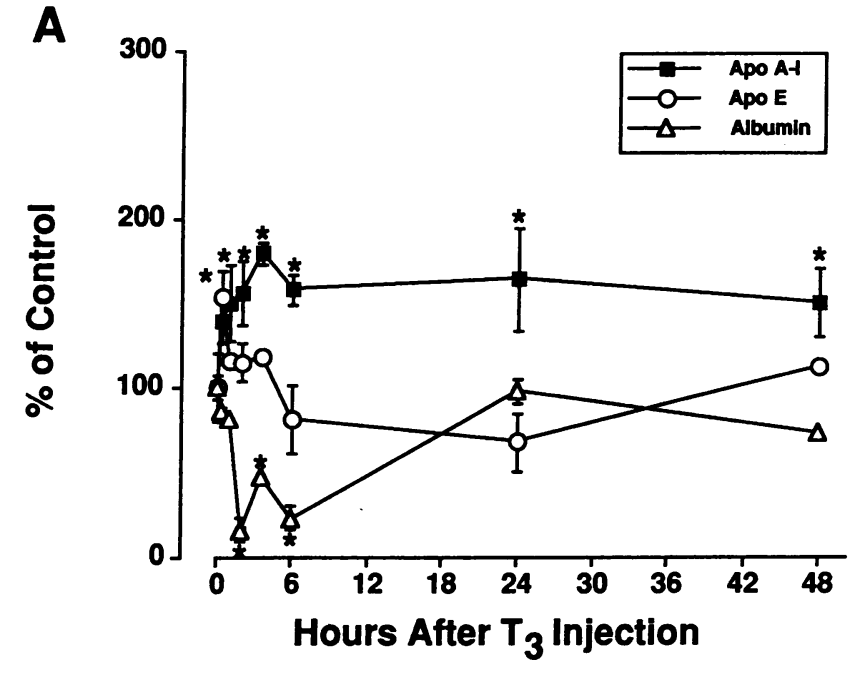

B

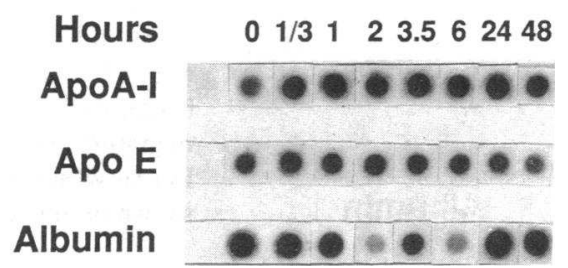

Figure 2. A, Time course of transcription rates of the apo A-I, apo E, and albumin genes in livers from rats after a single dose $(3 \mathrm{mg} / 100 \mathrm{~g}$ body weight i.p.) of $T_{3}$. Transcription rates were determined by runon assays using isolated liver cell nuclei from three to four animals per time point. Two independent assays were performed for each of the genes. Hybridization of the newly synthetized nuclear RNA to plasmids containing apo A-I, apo E, or albumin cDNA inserts were carried out in duplicate or triplicate. Data from the two assays were combined and expressed in percent of the 0 -h time point. Results are given as means $\pm \mathrm{SD}$ or means of duplicate determinations. ${ }^{*} P$ $<0.05$, analysis of variance. $B$, Representative dot blots illustrating the relative transcription rates of the apo A-I, apo E, and albumin genes after a single dose of $3 \mathrm{mg} / 100 \mathrm{~g}$ body weight of $T_{3}$ i.p. as determined in the run-on transcription assay shown in numerical form in $A$.

creased rate of albumin mRNA synthesis was associated with a transient fall in nuclear albumin RNA. The higher molecular weight bands of nuclear albumin RNA decreased to a greater extent than the smaller ones at the 2 -h time point. The relationship of synthesis and abundance of nuclear and total cellular apo A-I, apo E, and albumin mRNA is illustrated in Fig. 4. Total cellular apo A-I mRNA, as determined by quantitative slot blotting, was increased $2 \mathrm{~h}$ after the injection and continued to rise to $298 \%$ of control levels at $24 \mathrm{~h}$. Cellular apo E mRNA abundance remained unaltered during the period studied, while abundance of cellular albumin mRNA decreased slightly at $24 \mathrm{~h}$.

The decrease of albumin mRNA synthesis could have resulted from an inflammatory response (34), perhaps induced by the intraperitoneal injection of alkaline saline. To rule out this confounding variable, a fourth group of rats was injected with $100 \mu \mathrm{l} / 100 \mathrm{~g}$ body weight of $0.9 \% \mathrm{NaCl}$ i.p., pH 11, or with $100 \mu \mathrm{l}$ of $0.9 \% \mathrm{NaCl}$, pH 11 , containing $50 \mu \mathrm{g} \mathrm{T} / 100 \mathrm{~g}$ body weight. Animals were killed $6 \mathrm{~h}$ later. Nuclear apo A-I, apo E, and albumin RNA content were measured by Northern blotting. No effect of the saline injection on the abundance of these nuclear RNA species was observed. In $\mathrm{T}_{3}$-injected animals, nuclear apo A-I RNA content increased to $193 \%$ of control, while nuclear albumin RNA decreased to $45 \%$ of control. The abundance of nuclear apo E RNA did not differ among control, control-injected, and $T_{3}$-injected animals. Since abundance of nuclear albumin and apo A-I RNA reflects mRNA synthesis at this time point (Fig. 4), these data clearly show that thyroid hormone rather than inflammation was responsible for the acute changes in apo A-I and albumin mRNA synthesis shown in Figs. 2 and 4. Our short-term time-course experiment then indicated that enhanced apo A-I mRNA synthesis accounted only for a fraction of the increase in nuclear and total cellular apo A-I mRNA content at the 24-h time point (Fig. 4). This relationship between mRNA synthesis and nuclear RNA abundance implicates again a major role of stabilization of nuclear apo A-I RNA in the regulation of apo A-I gene expression in rat liver.

To confirm the contrasting effects of long- and short-term $\mathrm{T}_{3}$ administration on apo A-I transcription rates in one group of animals and to determine whether very high doses of $T_{3}$ when administered repeatedly also reduce apo A-I transcription rates, a fifth group of rats was studied (Table IV). As observed in previous experiments, transcription was increased $6 \mathrm{~h}$ after a single dose of 50 or $500 \mu \mathrm{g} \mathrm{T}_{3} / 100 \mathrm{~g}$, but was decreased after chronic administration. Nuclear and total cellular apo A-I mRNA concentration tended to be higher $6 \mathrm{~h}$ after the injection and was substantially increased after $7 \mathrm{~d}$ of hormone administration.

\section{Discussion}

The principal conclusion of our studies is that the stimulation of apo A-I gene expression by thyroid hormones in rat liver is complex. Depending on the duration of the thyroid status, rates of apo A-I gene transcription and/or stabilization of nuclear apo A-I mRNA precursors play a major role in altering hepatic apo A-I mRNA. Chronic hypothyroidism induced by propylthiouracil reduced apo A-I mRNA levels to approximately half of euthyroid control values without changes in apo E or albumin mRNA abundance (Table I) as reported previously $(9,11)$. The decrease of total cellular apo A-I mRNA was accompanied by a fall in the apo A-I gene transcription rate of similar magnitude. The reduced rates of apo A-I mRNA synthesis can therefore explain the diminished apo A-I mRNA abundance and the decreased apo A-I production in hypothyroid rats (10) as suggested in a previous studies (41). Thus, thyroid hormones may be required to maintain the normal basal rate of apo A-I biosynthesis in rat liver.

Injection of $T_{3}$ into euthyroid animals rapidly increased apo A-I transcription. The increased apo A-I mRNA synthesis rate was detected $20 \mathrm{~min}$ after hormone injection, which was the earliest time point studied. This suggests a direct interaction of the $T_{3}$ receptor complex with the apo A-I gene. $6 \mathrm{~h}$ after the injection, maximal increases in apo A-I gene transcription were observed with a dose of $50 \mu \mathrm{g} \mathrm{T}_{3} / 100 \mathrm{~g}$ body weight, and no further increase was noted with 500 or $3,000 \mu \mathrm{g} / 100 \mathrm{~g}$ (Fig. 2 , Table IV). However, the stimulation of transcription by very high doses of $\mathrm{T}_{3}$ may extend over longer periods of time, as apo A-I mRNA synthesis was still elevated at $48 \mathrm{~h}$ after $3 \mathrm{mg}$ 


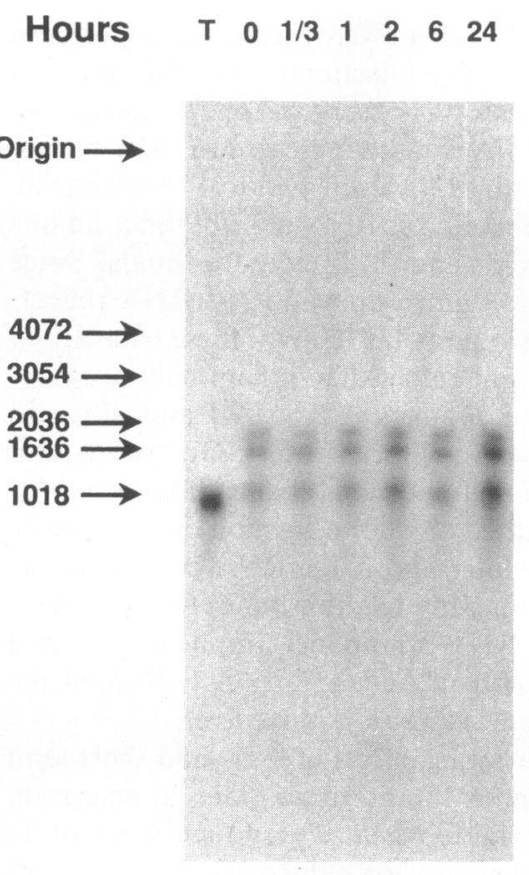

ApoA-1
$\begin{array}{lllllll}T & 0 & 1 / 3 & 1 & 2 & 6 & 24\end{array}$

$\begin{array}{lllllll}T & 0 & 1 / 3 & 1 & 2 & 6 & 24\end{array}$

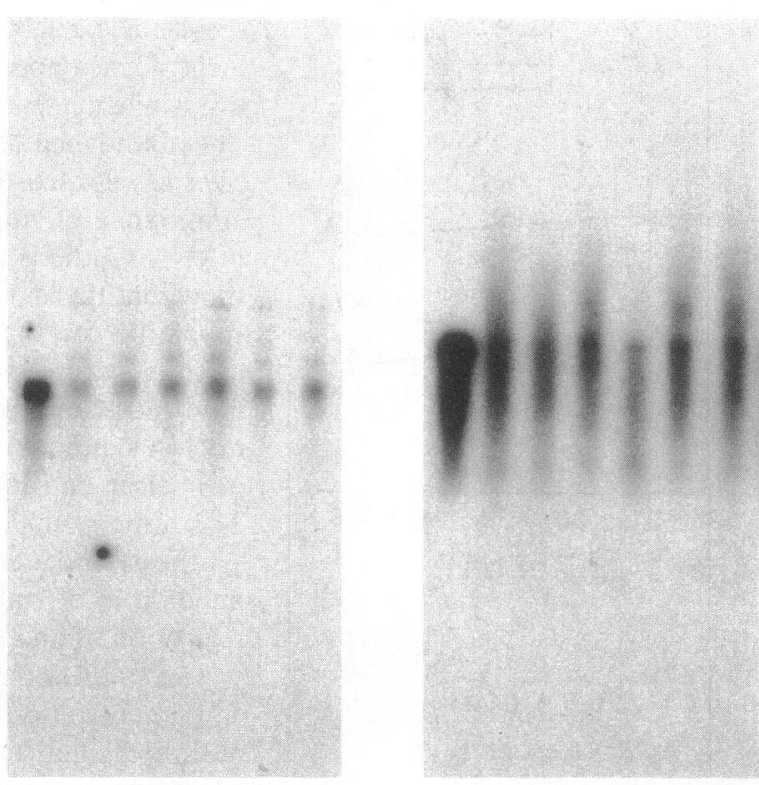

Apo E
Albumin
Figure 3. Time course of abundance of nuclear apo A-I, apo E, and albumin mRNA precursors after a single injection of $3 \mathrm{mg}$ $\mathrm{T}_{3} / 100 \mathrm{~g}$ body weight. $T$, total cellular RNA (10 $\mu \mathrm{g}) ; 0,1 / 3,1,2,6$, and 24 , nuclear RNA (25 $\mu \mathrm{g})$ of rats killed $0 \mathrm{~min}, 20$ $\min , 1 \mathrm{~h}, 2 \mathrm{~h}, 6 \mathrm{~h}$, and 24 $h$ after the injection. The migration distance of molecular weight markers is shown on the left.
$\mathrm{T}_{3} / 100 \mathrm{~g}$ (Fig. 2), while daily injections of $35 \mu \mathrm{g} / 100 \mathrm{~g}$ for $3 \mathrm{~d}$ resulted in decreased transcription rates (Table III). Nevertheless, daily injections of very high doses of $\mathrm{T}_{3}$ led to reduced apo A-I transcription rates as well (Table IV). Our studies showed a maximal increase of apo A-I transcription of $70 \%$ at $6 \mathrm{~h}$ after hormone injection. Because apo A-I transcription was reduced by half in hypothyroid rats, the magnitude of the increase of
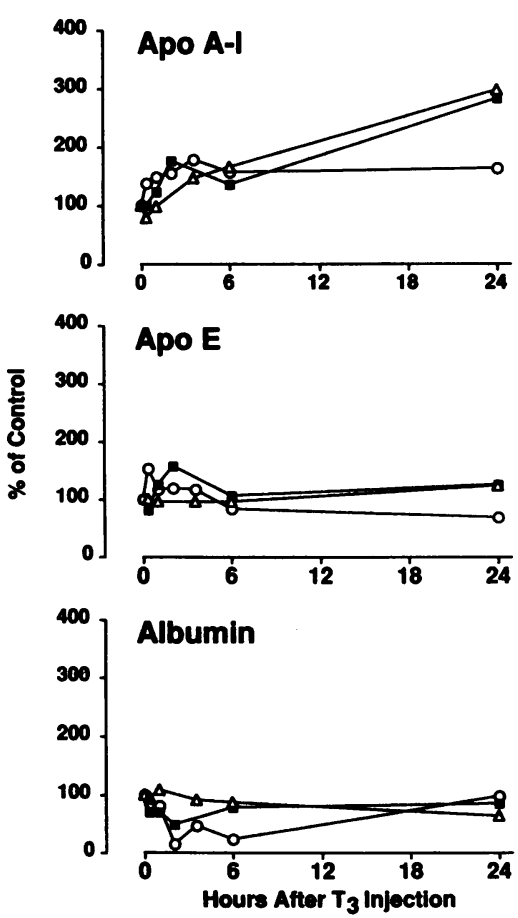

Figure 4. Time course of transcription rates (o), nuclear RNA levels $(\boldsymbol{)}$, and total cellular mRNA abundance $(\Delta)$ for the apo A-I, apo E, and albumin genes in livers from rats injected with a single dose of $T_{3}$ ( $3 \mathrm{mg} / 100$ g i.p.). Transcription rates are the same as in Fig. 2. Nuclear RNA levels were quantified in the same animals by scanning of Northern blots shown in Fig. 3. Total cellular mRNA levels were measured by quantitative slot blotting and are means of three to four determinations at three concentrations each per time point. All data are expressed as percent of the 0 time point. apo A-I mRNA synthesis may be three- to fourfold when the hormone status of animals is acutely changed from hypo- to hyperthyroid.

Thyroid hormones are known to increase transcription of a

Table IV. Effect of Short- vs. Long-term $T_{3}$ Administration on Hepatic Apo A-I Gene Transcription and Abundance of Nuclear Apo A-I MRNA

\begin{tabular}{ccccc}
\hline Treatment & Time & $\begin{array}{c}\text { Synthesis } \\
\text { of apo A-I } \\
\text { mRNA }\end{array}$ & $\begin{array}{c}\text { Abundance } \\
\text { of nuclear } \\
\text { apo A-I RNA }\end{array}$ & $\begin{array}{c}\text { Abundance } \\
\text { of total cellular } \\
\text { apo A-I RNA }\end{array}$ \\
\hline & & $p p m$ & \multicolumn{2}{c}{$\%$ of control } \\
Control & - & $70 \pm 6$ & 100 & $100 \pm 11$ \\
$50 \mu \mathrm{g} \mathrm{T}_{3}$ & $6 \mathrm{~h}$ & $116 \pm 9^{*}$ & 130,180 & $125 \pm 8$ \\
$500 \mu \mathrm{g} \mathrm{T}_{3}$ & $6 \mathrm{~h}$ & $107 \pm 6^{*}$ & 210,220 & $157 \pm 22$ \\
Saline & $7 \mathrm{~d}$ & $82 \pm 10$ & 103,84 & $126 \pm 8$ \\
$50 \mu \mathrm{g} \mathrm{T}_{3}$ & $7 \mathrm{~d}$ & $56 \pm 3^{*}$ & 258,232 & $243 \pm 31^{*}$ \\
$500 \mu \mathrm{g} \mathrm{T}_{3}$ & $7 \mathrm{~d}$ & $47 \pm 2^{*}$ & 416,351 & $378 \pm 34^{*}$ \\
\hline
\end{tabular}

Liver cell nuclei were isolated from rats $6 \mathrm{~h}$ after a single injection of $T_{3}$ or after $7 \mathrm{~d}$ of $\mathrm{T}_{3}$ administration ( 50 or $500 \mu \mathrm{g} / 100 \mathrm{~g}$ body weight per $d$ i.p.). Nuclei $\left(5 \times 10^{7}\right)$ from four animals per group were pooled and allowed to continue RNA synthesis in the presence of $\left[{ }^{32} \mathrm{P}\right]$ UTP. The newly synthetized $\left[{ }^{32} \mathrm{P}\right] \mathrm{RNA}$ was hydridized in triplicate to plasmids containing apo A-I cDNA inserts immobilized on filters. mRNA synthesis rates are expressed as parts per million and are corrected for hybridization efficiency $(36 \pm 3 \%)$ and are means $\pm S D$. Apo A-I nuclear RNA abundance was determined by soft laser densitometry of autoradiographs of Northern blots hybridized to [ $\left.{ }^{32} \mathrm{P}\right]$ apo A-I cDNA. Abundance of total cellular apo A-I mRNA (mean \pm SEM) was determined by quantitative slot blotting.

* Significantly different from control $(P<0.05$, analysis of variance, Scheffe test). 
number of genes, of which the growth hormone gene has been studied most extensively. In rat pituitary tumor cells, growth hormone gene transcription increases in proportion to the occupancy of nuclear $T_{3}$ receptor sites (42). These and other experiments (43) support the notion that enhanced transcription involves the binding of the nuclear $T_{3}$ receptor complex to cis-acting sequences in the $5^{\prime}$ flanking region of the growth hormone gene. Such thyroid hormone-responsive elements have been identified in stable and transient transfection studies (44-46), but the precise location of the sequence functioning as the dominant thyroid hormone response element in vivo may require further studies (14). The cis- and trans-acting elements regulating apo A-I gene expression are incompletely understood. An enhancer-like element in the $5^{\prime}$ flanking region of the rat apo A-I gene has been described (47), and cis-acting elements controlling the expression of the human apo A-I gene in different cell types have been characterized (48). Identification of the thyroid hormone-responsive elements of the rat apo A-I gene awaits further experimentation, including transfection studies. Besides the acute stimulatory effect of $T_{3}$ on apo A-I gene transcription, a temporary rise in apo $\mathrm{E}$ gene transcription was also observed. By contrast, albumin gene transcription was acutely decreased (Fig. 2; data not shown). Inhibition of transcription by $T_{3}$ has been shown for several genes, including that of thyrotropin $(49,50)$ and $\beta$-myosin heavy chain $(51,52)$.

Our short-term time-course experiment demonstrates, however, that the increase of apo A-I gene transcription was not sufficient to explain the increase of nuclear and total cellular apo A-I mRNA at $24 \mathrm{~h}$ after hormone administration. The increase in nuclear apo A-I RNA preceded that of total cellular apo A-I mRNA. A similar rapid rise of nuclear RNA that cannot be explained solely by enhanced transcription occurs in the activation of $\mathrm{S} 14$ gene expression by thyroid hormones $(17,53)$. Thus, stabilization of nuclear mRNA precursors as suggested by Narayan and Towle for the S14 gene (18) may also be implicated in the stimulation of apo A-I gene expression by $T_{3}$. Intranuclear stabilization of primary transcripts has been established as a regulatory mechanism of gene expression. Leys et al. took advantage of the 500 -fold amplification of the dihydrofolate reductase gene in methotrexate-resistant mouse cells and showed in continuous labeling experiments that the fraction of dihydrofolate reductase transcripts that are converted to mature mRNA depends on the growth status of cells (54). The mechanism for such stabilization is not known, but may involve protection from or decreased activity of ribonucleases. Thyroid hormones have been shown to increase posttranscriptional editing of apo B mRNA, leading to an increased production of apo B-48 at the expense of apo B-100 (13). Sequence modifications at the posttranscriptional level could thus be involved in conferring increased stability to transcripts of the apo A-I gene.

As described previously by Apostolopoulos et al. (9) and Davidson et al. (11), chronic hyperthyroidism induced by repeated administration of $T_{4}$ or $T_{3}$ increased the abundance of hepatic apo A-I mRNA without changes in apo $\mathrm{E}$ and albumin mRNA levels (Tables I and III; Fig. 1). We now show that the transcription rate of the apo A-I gene decreased in hyperthyroid animals when compared with euthyroid rats. This was a consistent finding in five transcription assays performed on nuclei of three independent sets of animals (Tables I, III, and IV; and Fig. 1). Posttranscriptional events are therefore solely responsible for the enhanced apo A-I gene expression in livers of chronic hyperthyroid rats. Since nuclear apo A-I RNA remained elevated, stabilization of nuclear apo A-I RNA is the most likely mechanism. Considering a 3.5-fold elevation of apo A-I mRNA levels and a 50\% reduction of the transcription rate (Tables I, III, and IV), the posttranscriptional events may lead to a sevenfold increase of cellular apo A-I mRNA and may thus exceed the magnitude of thyroid hormone-dependent transcriptional regulation. Our data furthermore imply that in the euthyroid state the majority of nuclear apo A-I RNA is not processed to mature mRNA, but is degraded in the nucleus.

The reduced rate of apo A-I gene transcription associated with increased levels of nuclear apo A-I RNA in chronic hyperthyroidism is a potentially important observation. The inverse relationship between transcription rate and mRNA abundance was substantiated in experiments where differential increases of apo A-I mRNA levels were attained (Tables III and IV). Although decreased synthesis and increased abundance of apo A-I mRNA was a consistent finding in all sets of animals with chronic hyperthyroidism, variability existed regarding the magnitude of this inverse relationship. When compared with rats receiving $35 \mu \mathrm{g} \mathrm{T}_{3} / 100 \mathrm{~g}$ body weight s.c. for $7 \mathrm{~d}$ (Table III), the abundance of nuclear and cellular apo A-I mRNA was $\sim 35 \%$ higher in animals receiving $500 \mu \mathrm{g}$ $\mathrm{T}_{3} / 100 \mathrm{~g}$ body weight i.p. daily for $7 \mathrm{~d}$; yet, mRNA synthesis was reduced by a lesser extent. This may be related to the experimental error inherent in the procedures used and/or to variability between groups of animals. However, the relationship of apo A-I mRNA synthesis and abundance in hyperthyroidism is probably complex, and the interplay of stimulatory and inhibitory factors may depend on the dose of $T_{3}$ and the duration of the hyperthyroid state. An inverse relationship between synthesis and abundance of apo A-I mRNA is consistent with the notion that apo A-I gene transcription may be subject to feedback regulation. Degradation of nuclear apo A-I RNA could have a positive effect on apo A-I gene transcription. Apo A-I RNA fragments may perhaps compete with a cis element for a transcription factor that represses transcription from the apo A-I gene. Since the majority of nuclear apo A-I RNA is degraded in the euthyroid state, only minor increases in the concentration of apo A-I RNA degradation products would be expected in the hypothyroid state. The relationship between apo A-I mRNA synthesis and mRNA concentration should therefore be similar in euthyroid and hypothyroid rats, which was observed by us (Table I) and others (41). This hypothesis on autoregulation of apo A-I transcription deserves experimental testing, since useful information about the regulation of eukaryotic gene expression may be obtained.

\section{Acknowledgments}

This work was supported by National Institutes of Health grant R01 HL-34457. Dr. Strobl was a recipient of a fellowship made available through the Max Kade Foundation, Inc., New York, NY.

\section{References}

1. Wu, A.-L., and H. G. Windmueller. 1979. Relative contributions by liver and intestine to individual plasma apolipoproteins in the rat. J. Biol. Chem. 254:7314-7322.

2. Patsch, W., S. Franz, and G. Schonfeld. 1983. Role of insulin in 
lipoprotein secretion by cultured rat hepatocytes. J. Clin. Invest. 71:1161-1174.

3. Patsch, W., A. M. Gotto, Jr., and J. R. Patsch. 1986. Effects of insulin on lipoprotein secretion in rat hepatocyte cultures: the role of the insulin receptor. J. Biol. Chem. 261:9603-9606.

4. Sparks, C. D., J. D. Sparks, M. Bolognino, A. Salhanick, P. S. Strumph, and J. M. Amatruda. 1986. Insulin effects on apolipoprotein B-lipoprotein synthesis and secretion by primary cultures of rat hepatocytes. Metab. Clin. Exp. 35:1128-1136.

5. Elshourbagy, N., M. S. Boguski, W. S. Liao, L. S. Jefferson, J. L. Gordon, and J. M. Taylor. 1985. Expression of rat apolipoprotein A-IV and A-I genes: mRNA induction during development and in response to glucocorticoids and insulin. Proc. Natl. Acad. Sci. USA. 82:8242-8246.

6. Chan, L., R. L. Jackson, B. W. O'Malley, and A. R. Means. 1976. Synthesis of very low density lipoproteins in the cockerel: effects of estrogen. J. Clin. Invest. 58:368-379.

7. Miller, K. W., and D. M. Lane. 1984. Estradiol-induced alteration of very-low-density lipoprotein assembly: possible competition among apoproteins for incorporation into nascent very-low-density lipoproteins. J. Biol. Chem. 259:15277-15286.

8. Patsch, W., K. Kim, W. Wiest, and G. Schonfeld. 1980. Effects of sex hormones on rat lipoproteins. Endocrinology. 107:1074-1085.

9. Apostolopoulos, J. J., G. J. Howlett, and N. Fidge. 1987. Effects of dietary cholesterol and hypothyroidism on rat apolipoprotein mRNA metabolism. J. Lipid Res. 28:642-648.

10. Wilcox, H. G., W. G. Keyes, T. A. Hale, R. Frank, D. W. Morgan, and M. Heimberg. 1982. Effects of triiodothyronine and propylthiouracil on plasma lipoproteins in male rats. J. Lipid Res. 23:1159-1166.

11. Davidson, N. O., R. C. Carlos, M. J. Drewek, and T. G. Parmer. 1988. Apolipoprotein gene expression in the rat is regulated in a tissue-specific manner by thyroid hormone. J. Lipid Res. 29:1511-1522.

12. Heimberg, M., J. O. Olubadewo, and H. G. Wilcox. 1985. Plasma lipoproteins and regulation of hepatic metabolism of fatty acids in altered thyroid states. Endocr. Rev. 6:590-607.

13. Davidson, N. O., L. M. Powell, S. C. Wallis, and J. Scott. 1988. Thyroid hormone modulates the introduction of a stop codon in rat liver apolipoprotein B messenger RNA. J. Biol. Chem. 263:1348213485.

14. Olubadewo, J., H. G. Wilcox, and M. Heimberg. 1984. Modulation by glycerol of hepatic glycero-3-phosphate concentration, ketogenesis, and output of triglyceride and glucose in perfused livers from hyperthyroid and euthyroid rats. J. Biol. Chem. 259:8857-8862.

15. Samuels, H. H., B. M. Forman, Z. D. Horowitz, and Z.-S. Ye. 1988. Regulation of gene expression by thyroid hormone. J. Clin. Invest. 81:957-967.

16. Izumo, S., and V. Mahdavi. 1988. Thyroid hormone receptor isoforms generated by alternative splicing differentially activate myosin HC gene transcription. Nature (Lond.). 334:539-542.

17. Mueckler, M. M., S. Moran, and H. C. Pitot. 1984. Transcriptional control of ornithine aminotransferase synthesis in rat kidney by estrogen and thyroid hormone. J. Biol. Chem. 259:2302-2305.

18. Narayan, P., and H. C. Towle. 1985. Stabilization of a specific nuclear mRNA precursor by thyroid hormone. Mol. Cell. Biol. 5:2642-2646.

19. Perez-Castillo, A., H. L. Schwartz, and J. H. Oppenheimer. 1987. Rat hepatic mRNA-S 14 and lipogenic enzymes during weaning: role of S14 in lipogenesis. Am. J. Physiol. E536-E542.

20. Dozin, B., M. A. Magnuson, and V. M. Nikodem. 1986. Thyroid hormone regulation of malic enzyme synthesis: dual tissue-specific control. J. Biol. Chem. 261:10290-10292.

21. Simonet, W. S., and G. C. Ness. 1988. Transcriptional and posttranscriptional regulation of rat hepatic 3-hydroxy-3-methylglutaryl-coenzyme A reductase by thyroid hormones. J. Biol. Chem. 263:12448-12453.

22. Strobl, W., N. Gorder, Y.-C. Lin-Lee, G. Fienup, A. M. Gotto, Jr., and W. Patsch. 1989. The role of thyroid hormone in hepatic apolipoprotein A-I gene expression in the rat. Clin. Res. 37:300A. (Abstr.)

23. Siedel, J., E. O. Hagele, J. Ziegenhorn, and A. W. Wahlefeld. 1983. Reagent for the enzymatic determination of serum total cholesterol with improved lipolytic efficiency. Clin. Chem. 29:1075-1080.

24. Nagele, U., E. O. Hagele, G. Sauer, E. Widermann, P. Lehmann, A. W. Wahlefeld, and W. Gruber. 1984. Reagent for the enzymatic determination of serum triglycerides with improved lipolytic efficiency. J. Clin. Chem. Clin. Biochem. 22:165-174.

25. Patsch, W., T. Tamai, and G. Schonfeld. 1983. Effect of fatty acids on lipid and apoprotein secretion and association in hepatocyte cultures. J. Clin. Invest. 72:371-378.

26. McLean, J. W., C. Fukuzawa, and J. Taylor. 1983. Rat apolipoprotein E mRNA: cloning and sequencing of double-stranded cDNA. J. Biol. Chem. 258:8993-9000.

27. Strobl, W., N. L. Gorder, G. A. Fienup, Y.-C. Lin-Lee, A. M. Gotto, Jr., and W. Patsch. 1989. Effect of sucrose diet on apolipoprotein biosynthesis in rat liver: increase in apolipoprotein $E$ gene transcription. J. Biol. Chem. 264:1190-1194.

28. Sargent, T. D., M. Yang, and J. Bonner. 1980. Nucleotide sequence of cloned rat serum albumin messenger RNA. Proc. Natl. Acad. Sci. USA. 78:243-246.

29. Rigby, P. W., M. Dieckmann, C. Rhodes, and P. Berg. 1977. Labeling deoxyribonucleic acid to high specific activity in vitro by nick translation with DNA polymerase I. J. Mol. Biol. 113:237-251.

30. Lin-Lee, Y.-C., F.-T. Kao, P. Cheung, and L. Chan. 1985. Apolipoprotein $\mathrm{E}$ gene mapping and expression: localization of the structural gene to human chromosome 19 and expression of apoE mRNA in lipoprotein and non-lipoprotein-producing tissues. Biochemistry. 24:3751-3756.

31. Thomas, P. 1980. Hybridization of denatured RNA and small DNA fragments transferred to nitrocellulose. Proc. Natl. Acad. Sci. USA. 77:5201-5205.

32. Northemann, W., M. Heisig, D. Kunz, and P. C. Heinrich. 1985. Molecular cloning of cDNA sequences for rat $\alpha_{2}$-macroglobulin and measurement of its transcription during experimental inflammation. J. Biol. Chem. 260:6200-6205.

33. Kapuscinski, J., and B. Skoczylas. 1977. Simple and rapid fluorimetric method for DNA microassay. Anal. Biochem. 83:252257.

34. Birch, H. E., and G. Schreiber. 1986. Transcriptional regulation of plasma protein synthesis during inflammation. J. Biol. Chem. 261:8077-8080.

35. Groudine, M., M. Peretz, and H. Weintraub. 1981. Transcriptional regulation of hemoglobin switching in chicken embryos. Mol. Cell. Biol. 1:281-288.

36. Turcotte, B., M. Guertin, M. Chevrette, and L. Belanger. 1985. Rat $\alpha_{1}$-fetoprotein messenger RNA: 5'-end sequence and glucocorticoid-suppressed liver transcription in an improved nuclear run-off assay. Nucleic Acids Res. 13:2387-2398.

37. Roop, D. R., J. L. Nordstrom, S. Tsai, M. J. Tsai, and B. W. O'Malley. 1978. Transcription of structural and intervening sequences in the ovalbumin gene and identification of potential ovalbumin mRNA precursors. Cell. 15:671-685.

38. Spindler, S. R., S. H. Mellon, and J. D. Baxter. 1982. Growth hormone gene transcription is regulated by thyroid and glucocorticoid hormones in cultured rat pituitary tumor cells. J. Biol. Chem. 257:11627-11632.

39. Lamers, W. H., R. W. Hanson, and H. M. Meisner. 1982. cAMP stimulates transcription of the gene for cytosolic phosphoenolpyruvate carboxykinase in rat liver nuclei. Proc. Natl. Acad. Sci. USA. 79:5137-5141.

40. Oppenheimer, J. H., H. L. Schwartz, and M. I. Surks. 1975. Nuclear binding capacity appears to limit the hepatic response to 1triiodothyronine $\left(\mathrm{T}_{3}\right)$. Endocr. Res. Commun. 2:309-325.

41. Apostolopoulos, J. J., M. J. La Scala, and G. J. Howlett. 1988. The effect of triiodothyronine on rat apolipoprotein A-I and A-IV gene transcription. Biochem. Biophys. Res. Commun. 154:997-1002. 
42. Nyborg, J. K., A. P. Nguyen, and S. R. Spindler. 1984. Relationship between thyroid and glucocorticoid hormone receptor occupancy, growth hormone gene transcription, and mRNA accumulation. J. Biol. Chem. 259:12377-12381.

43. Yaffe, B. M., and H. H. Samuels. 1984. Hormonal regulation of the growth hormone gene: relationship of the rate of transcription to the level of nuclear thyroid hormone-receptor complexes. J. Biol. Chem. 259:6284-6291.

44. Glass, C. K., R. Franco, C. Weinberger, V. Albert, R. Evans, and M. G. Rosenfeld. 1987. A c-erb-A binding site in rat growth hormone gene mediates trans-activation by thyroid hormone. Nature (Lond). 329:738-741.

45. Brent, G. A., P. R. Larsen, J. W. Harney, R. J. Koenig, and D. D. Moore. 1989. Functional characterization of the rat growth hormone promoter elements required for induction by thyroid hormone with and without a co-transfected $\beta$ type thyroid hormone receptor. J. Biol. Chem. 264:178-182.

46. Flug, F., R. P. Copp, J. Casanova, Z. D. Horowitz, L. Janocko, M. Plotnick, and H. H. Samuels. 1987. Cis-acting elements of the rat growth hormone gene which mediate basal and regulated expression by thyroid hormone. J. Biol. Chem. 262:6373-6382.

47. Chao, Y. S., X. H. Ding, P. H. Dai, T. P. Wu, Q. L. Hao, and T.-T. Yamin. 1988. Identification of an enhancer-like element in the $5^{\prime}$ flanking region of the rat apolipoprotein A-I gene. Nucleic Acids Res. 16:7061-7070.

48. Sastry, K. N., U. Seedorf, and S. K. Karathanasis. 1988. Different cis-acting DNA elements control expression of the human apolipoprotein A-I gene in different cell types. Mol. Cell. Biol. 8:605-614.

49. Shupnik, M. A., W. W. Chin, J. F. Habener, and E. C. Ridgway. 1985. Transcriptional regulation of the thyrotropin subunit genes by thyroid hormone. J. Biol. Chem. 260:2900-2903.

50. Carr, F. E., L. R. Need, and W. W. Chin. 1987. Isolation and characterization of the rat thyrotropin $\alpha$-subunit gene. J. Biol. Chem. 262:981-987.

51. Sinha, A. M., P. K. Umeda, C. J. Kavinsku, C. Rajamanickam, J.-J. Hsu, S. Jakovic, and M. M. Rabinowitz. 1982. Molecular cloning of mRNA sequences for cardiac $\alpha$ - and $\beta$-form myosin heavy chains: expression in ventricles of normal, hypothyroid, and thyrotoxic rabbits. Proc. Natl. Acad. Sci. USA. 79:5847-5851.

52. Lompre, A.-M., B. Nadal-Ginard, and V. Mahdavi. 1984. Expression of the cardiac ventricular $\alpha$-and $\beta$-myosin heavy chain genes is developmentally and hormonally regulated. J. Biol. Chem. 259:6437-6446.

53. Jump, D. B. 1989. Rapid induction of rat liver S14 gene transcription by thyroid hormone. J. Biol. Chem. 264:4698-4703.

54. Leys, E. J., G. F. Crouse, and R. E. Kellems. 1984. Dihydrofolate reductase gene expression in cultured mouse cells is regulated by transcript stabilization in the nucleus. J. Cell Biol. 99:180-187. 